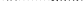 \\ 論 文 \\ UDC $\quad 536.421 .4: 669.112 .2: 536.4$

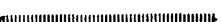 \\ 平衡状態図に基づいた鉄鋼の凝固モデル*
}

渡 辺 一 雄**

\section{A Mathematical Model of Solidification Based on the Fe-C System Equilibrium Phase Diagram}

\section{Kazuo Watanabe}

Synopsis:

A mathematical model for the estimation of the solidification processes of steels of various carbon concentrations has been made.

In this model, it is assumed that the latent heat release is proportional to the solid precipitation volume, and the solid precipitations of each $\delta$ and $\gamma$ phases and also the latter at the peritectic point based on the $\mathrm{Fe}-\mathrm{C}$ equilibrium phase diagram are considered.

The calculated time-temperature curve shows the constant-temperature time at the liquidus, and the higher the initial liquid carbon concentration, the shorter is the constant-temperature time.

From the distributions of the solid fraction for various initial liquid carbon concentrations, it is induced that the initial high carbon concentration is one of the factors to promote the equiaxed grain growth, on the contrary the low carbon concentration to promote the columnar grain growth.

\section{1. 緒言}

凝固過程の熱伝導解析については，最近，連続鋳造に 関して多くの報告がなされており，これらは，モールド， スプレ一水の冷却能など装置の機能，あるいは溶鋼の流 動など連続鋳造に特有な現象を取入れて論ぜられてい る.

一方, 凝固過程の熱伝導方程式の解析については, 古 くは NeUmann の解がある. また TIEN は, Goodman が 凝固など種々の相变化の問題に適用した積分プロフィル 法により，冷却側の温度 (境界值) が時間の関数である 場合について一般解を得た1)。これらの解は，一定の凝 固温度を持つ純金属に限られているが，TIEN らは 2 相 合金に拡張し, 固相率を固液共存層内の距離の 1 次関数 とした場合について解を求め2)，さらに固相率を温度の 関数とした場合についても解を得ているが，最終的には 数値解となり複雑なものとなつている. また, 宮沢, 鿒 は積分プロフィル法により連続鋳造における凝固問題を 解いており4), 固相率は温度の 1 次関数としている.

筆者は，鉄鋼における凝固現象を冷却温度曲線より観
察するという観点から，凝固現象をなるべく正確に取り 入れた熱伝導方程式を解くことにしたが，比較的複雑な 状態図を持つ $\mathrm{Fe}-\mathrm{C}$ 系合金について解析解を得ることは 非常に困難であり，差分方程式によつて解くこととし た.

本報告では， $\mathrm{Fe}-\mathrm{C}$ 系平衡状態図に彷つて固相が析出 するとの条件のもとに, 円柱状鋳片を対象として熱伝導 方程式を解き, 種々の炭素濃度について凝固時の冷却温 度曲線を求め, 考察を加えた。

\section{2. 熱伝導方程式}

熱伝導方程式は円筒座標によつた．長さ方向の温度変 化はないとすれば，熱伝導方程式は

$$
\frac{\partial H}{\partial t}=\frac{\kappa}{\rho}\left(\frac{\partial^{2} \theta}{\partial r^{2}}+\frac{1}{r} \frac{\partial \theta}{\partial r}\right)
$$

で表わされる. $\phi=\int_{0}^{0}\left(\kappa / \kappa_{0}\right) d \theta$ なる变換温度 $\phi$ を使用 して熱伝導方程式を記述する場合が多いが，ここでは温 度変化範囲が狭いので $\kappa$ を定数として取り扱うため, (1) 式は $\theta$ に関する方程式となつている，Hは㠜固潜熱 も含えでいるため当然温度の関数である.

* 昭和 48 年 4 月鉄鋼基礎共同研究会第 4 回凝固部会にて発表

昭和 50 年 2 月 19 日受付 (Received Feb. 19，1975)

**大同製鋼 (株) 研究開発本部中央研究所 (Central research laborotory, R \& D div. Daido Steel

Co. Ltd. 2-30, Daido-cho Minami-ku Nagoya 457) 


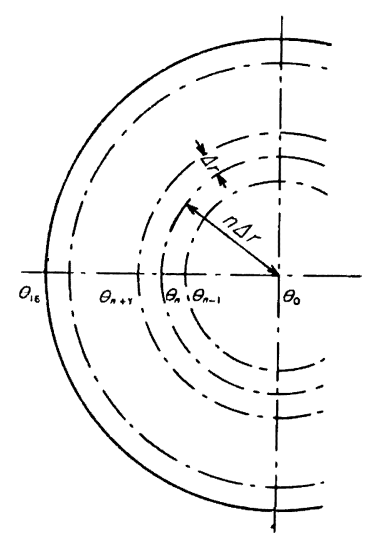

Fig. 1. Schematic representation of ingot.

(1)式を差分方程式にて記述すると, 中心軸上以外の 任意の点では,

$$
\begin{aligned}
& H_{n, t+\Delta t}=H_{n, t}+\frac{\kappa}{\rho} \frac{\Delta t}{J r^{2}}\left(\theta_{n+1, t}-2 \theta_{n, t}+\theta_{n-1, t}\right) \\
& +\frac{\kappa}{\rho} \frac{J t}{2\lrcorner r} \frac{1}{n\lrcorner r}\left(\theta_{n+1, t}-\theta_{n-1, t}\right) \\
& =H_{n, t}+\frac{\kappa}{\rho} \frac{J t}{J r^{2}}\left[\left(1+\frac{1}{2 n}\right) \theta_{n+1, t}-2 \theta_{n, t}\right. \\
& \left.+\left(1-\frac{1}{2 n}\right) \theta_{n+1, t}\right] \ldots \ldots \ldots \ldots \ldots \ldots \ldots \ldots \ldots \ldots \ldots \ldots \ldots \ldots \ldots \ldots \ldots \ldots \ldots
\end{aligned}
$$

である.（2)式の添字 $n$ は Fig. 1 に示すように，中心 軸からの各点の位置を表わす. 添字 $t+d t$ は時間 $t$ より $\Delta t$ 時間後の時間を表わす. 中心軸上については,

$$
H_{0, t}+J t=H_{0, t}+\frac{4 \kappa}{\rho} \frac{J t}{\Delta r^{2}}\left(\theta_{1}-\theta_{0}\right)
$$

である、なお，境界条件は鋳片の表面温度で与えられる ものとする・

\section{3. 凝固過程における温度と含熱量との関係 について}

(2)，（3)式により時間 $t$ における含熱量 $H_{n, t}$ と温

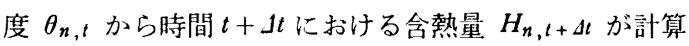
されるが, $H_{n, t+\Delta t}$ から時間 $t+\Delta t$ における温度 $\theta_{n, t+\Delta t}$ を求めるには, 温度と含熱量との関係を確立しておかね ばならない。凝固過程における含熱量の变化は主として 凝固潜熱の放熱と考えられ，放熱の割合は固相率に比例 するとすれば, 温度と含熱量との関係は, すなわち温度 と固相率の関係となる. この固相析出による潜熱の変化 と比熱による含熱量の変化の和が全体の含熱量の変化で あるとする.

固相の析出機構については, 次に述べる考え方があり,
それによつて温度と含熱量の関係も異なる。

i ）液相中および固相中の溶質濃度が均一である場 合. 平衡状態図にしたがつて固相および液相が存在し, 固相率は lever's ruleにより計算される.

ii）液相中の溶質濃度は均一であり, 固相中の溶質拡 散が全くない場合、PHANNが用いた固相率と析出固相濃 度の関係式5)より, 温度と固相率の関係が誘導される.

iii）固相析出に際して液相中に排出された溶質の液相 中における濃度分布の拡散または液相の流動によつて支 配される場合.

以上の場合について, 温度と固相率の関係を比較検討 すると, i) と ii) の場合は, 後出の Fig. AI に示す ように固相率が 0.3 程度になるまでは，それほど大きく 異なつていない，また，iii）の場合について検討すると 液相中の溶質濃度分布は凝固速度によつて異なり，した がつて温度と固相率の関係も凝固速度によつて異なり, 一定していない，熱伝導方程式を解くにあたつては温度 と固相率の関倸が決つていなければならないので，正確 な解を得るには熱伝導方程式と拡散方程式を連立して解 くこととなり, 複雑な問題となる. をた, 簡単に凝固速 度を一定と仮定しても，デンドライト間の溶質濃度分布 を求めることは，限られた場所にて境界值を指定する場 所（固液界面）が移動するという条件にて拡散方程式を 解くこととなり, やはり複雑である.

ところが，この溶質濃度分の影響が表われるのは比較 的凝固速度が速い場合であり，そして凝固終了点付近で あると考えられる.ここでは特殊鋼を対象として考えて いるが，特殊鋼では炭素をはじめ成分簡囲が広く，成分 による凝固の差違を検討する必要があり，本報告はこの 点に主眼を置いていることと, 特殊鋼の連続鋳造の場合, 普通鋼に比べて凝固速度が遅いことから，本モデルでは i ）によつて計算することとした. なお，ii）について は温度と固相率の関係について考察した。

\section{4. 平衡状態図による温度と含熱量の 関係式の誘導}

$\mathrm{Fe}-\mathrm{C}$ 系 2 相合金とし，固相および液相が $\mathrm{Fe}-\mathrm{C}$ 系平 衡状態図にしたがつて存在するものとする．計算は次の 仮定のもとに行なつた.

i ) 固相，液相中とも，それぞれ炭素濃度は均一であ る.

ii）平衡分配係数は $\delta+L$ 領域， $\gamma+L$ 領域において それぞれ一定である。

iii）固相析出に伴う発熱量は $\delta, \gamma$ にかかわらず固相 
析出量に比例する.

vi）凝固潜熱は炭素濃度にかかわらず一定である.

v）包晶点では,析出する固相による発熱だけを考え， 包晶反応による発熱は無視する.

温度と含熱量の関係式は, 全部液相である場合, 固相, 液相が共存する場合，全部固相である場合では異なる.

全部液相の場合には，比熱による項と凝固潜熱の和と なり，

$$
H=s \theta+H_{0}+L
$$

で表わされる. $H_{0}$ は凝固点付近における温度と含熱量 の関係を表わす直線の延長において，温度が零の場合の 含熱量の値である.

全部固相の場合，凝固潜熱はすべて放出されており，

$$
H=s \theta+H_{0}
$$

で表わされる.

次に, 固液共存範囲では潜熱は固相析出量に比例して 放出されており，

$$
H=s \theta+H_{0}+L f_{l}
$$

で表わされる. ここで， $f_{l}=1-f_{s}$ である． $f_{l}$ は平衡状 態図より下記のように表わされる.

一般に, 温度が液相線と固相線の間にある場合には， lever's ruleにより

$$
f_{l}=\left(C_{0}-C_{s}\right) /\left(C_{L}-C_{s}\right)
$$

となる．液相線および固相線をそれぞれ $\theta=m C+\theta_{0}$ ， $\left.\theta=m / k_{0}\right) C+\theta_{0}$ で表わすとすれば

$$
\begin{aligned}
& C_{L}=\left(\theta-\theta_{0}\right) / m \cdots \cdots \\
& C_{s}=\left(\theta-\theta_{0}\right) /\left(m / k_{0}\right)
\end{aligned}
$$

であり, (7)〜 (9) 式により

$$
f_{l}=\frac{k_{0}}{1-k_{0}} \frac{\theta-\left[\left(m / k_{0}\right) C_{0}+\theta_{0}\right]}{\theta_{0}-\theta}
$$

が得られる. 次に，(6)，(10)式より，

$$
H=s \theta+H_{0}+L \frac{k_{0}}{1-k_{0}} \frac{\theta-\left[\left(m / k_{0}\right) C_{0}+\theta_{0}\right]}{\theta_{0}-\theta}
$$

となる. (11) 式は, 温度が包晶点以外の固液共存篹用に ある場合の温度と含熱量の関係式である.

計算に(11)式を用いる場合には, 含熱量から温度を求 める必要があるため，(11)式は次のように変換される。

$$
\theta=\left(-b+\sqrt{\left.b^{2}-4 a c\right)} / 2 a\right.
$$

ここて

$$
\begin{aligned}
& a=-s \\
& b=H-H_{0}+L \frac{k_{0}}{1-k_{0}}+s \theta_{0} \\
& c=-\left[\left(H-H_{0}\right) \theta_{0}+L \frac{k_{0}}{1-k_{0}}\left(\frac{m}{k_{0}} C_{0}+\theta_{0}\right)\right]
\end{aligned}
$$

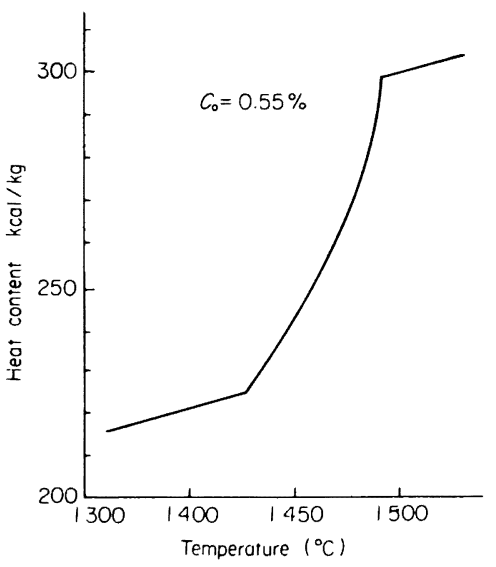

Fig. 2. Relation between temperature and heat content in the assumption of perfect diffusion of carbon in solid and liquid.

場合，数値に現実の意味がないからである.

計算時には，全部液相であるか，固液共存範囲である か，または全部固相であるかによつて，温度と含熱量の 関係式は，(4)式，(12)，(12') 式あるいは（5) 式のう ちいずれを使用するかを判定しなければならない.これ らの簡囲の境界の温度は (8)，(9)式より

$$
\begin{aligned}
& \theta_{1}=m C_{0}+\theta_{0} \cdots \cdots \\
& \theta_{4}=\left(m / k_{0}\right) C_{0}+\theta_{0}
\end{aligned}
$$

であり， $\theta_{1} ， \theta_{4}$ に対応する含熱量は，(4)，(5)，(13)，

(14) 式より,

$$
\begin{aligned}
& H_{1}=s\left(m C_{0}+\theta_{0}\right)+H_{0}+L \cdots \\
& H_{4}=s\left[\left(m / k_{0}\right) C_{0}+\theta_{0}\right]+H_{0}
\end{aligned}
$$

となる.すなわち，計算手順としては（2）式あるいは (3)式により求められた $H_{n, t+\lrcorner t}$ が $H_{n, t+\Delta t>H_{1}}$ なら ば(5) 式, $H_{1}>H_{n, t+J t}>H_{4}$ ならば(12) 式, $H_{4}>H_{n, t+\Delta t}$ ならば（6)式によつて温度 $\theta_{n, t}+J$ に変換される.

(4)式，(5)式，(12)式により， $C_{0}=0.55 \%$ の場合 について計算した温度と含熱量の関係を Fig. 2 に示し た. 式中の各数值は後出の Table 1 の值を使用した.

熱伝導計算の過程では固相率を直接求める必要はない が，固相率は lever's rule により

$$
\begin{aligned}
f_{s} & =\left(C_{L}-C_{0}\right) /\left(C_{L}-C_{s}\right) \\
& =\left(m C_{0}+\theta_{0}-\theta\right) /\left(1-k_{0}\right)\left(\theta_{0}-\theta\right)
\end{aligned}
$$

となる.しかし，本計算では $H$ 算出されているため， (6)式より,

$$
f_{s}=1-f_{l}=1-\left(H-s \theta-H_{0}\right) / L
$$

となり，Hから簡単に計算される. (18) 式は包晶点を含 导固液共存範囲に対しても成り立つ.

である. (12)式で平方根の前の符号を正としたのは負の 


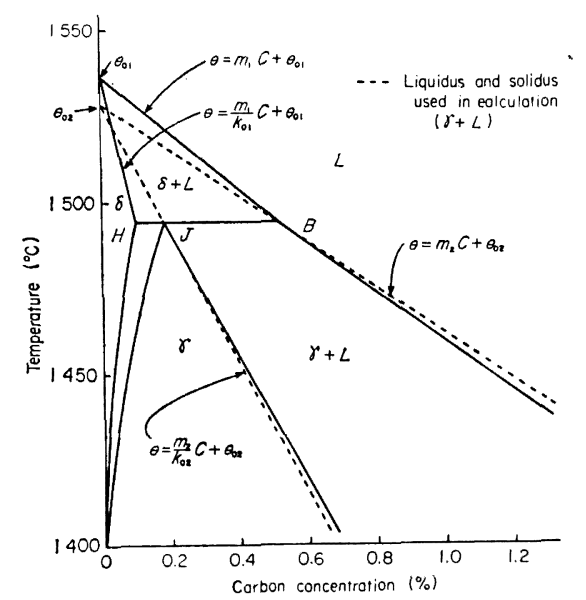

Fig. 3. Equilibrium phase diagram of $\mathrm{Fe}-\mathrm{C}$ system (by $R$. TANAKA $^{6}$ ) ) and liquidus and solidus used in calculation.

\section{Fe-C 系平衡状態図にしたがつた温度と 含熱量の関係式}

Fig. 3 に $\mathrm{Fe}-\mathrm{C}$ 系平衡状態図6)を示す. 温度と含熱 量の関係式は炭素濃度の 4 つの範囲でそれぞれ異なる.

1) $C_{0}<0.10 \%$

温度と含熱量の関係は Fig. 4a）に示すようになる。 $H_{1}, H_{4}$ は(15), (16)式にて $m=m_{1}, k_{0}=k_{01}$ とした

$$
\begin{aligned}
& H_{1}=s\left(m_{1} C_{0}+\theta_{01}\right)+H_{0}+L \ldots \\
& H_{4}=s\left[\left(m_{1} / k_{01}\right) C_{0}+\theta_{01}\right]+H_{0}
\end{aligned}
$$

である。

温度と含熱量の開係式はHの範囲により下記のようで ある。

i ） $H_{1}<H$ 全部液相であり, (4)式より $\theta=\left(H-H_{0}-L\right) /$

である。

ii ) $H_{4}<H<H_{1}$ 固液共存範囲であり, (12) 式で表わ される.ただし，(12)式中の $b, c$ の各値は $\left(12^{\prime}\right)$ 式で $m=m_{1}, k_{0}=k_{01}, \theta_{0}=\theta_{01}$ とした時の値である.

iii) $H<H_{4}$ 全部固相であり, (5)式より

$$
\theta=\left(H-H_{0}\right) / s
$$

である・

$$
\text { 2) } 0.10 \%<C_{0}<0.18 \%
$$

凝固過程に包晶点を含み, 包晶点で㠜固が終了する. 温度と含熱量との関係は Fig. 4b) に示すようになる. $\mathrm{H}_{2}$ は温度が包晶点に到達した時間の $H$ であるから， (11)式にて $m=m_{1}, k_{0}=k_{01}, \theta_{0}=\theta_{01}$ ，かつ $\theta=\theta_{p}$ とすれ ば， $H_{2}$ が求まる. $H_{1}, H_{2}, H_{3}$ は次のようである.

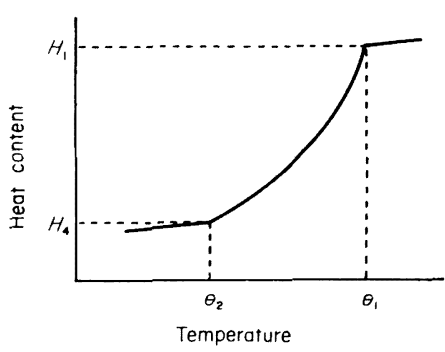

a)

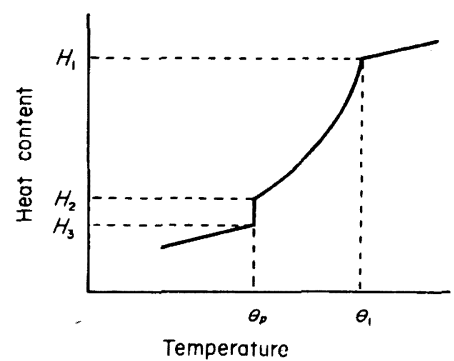

b)

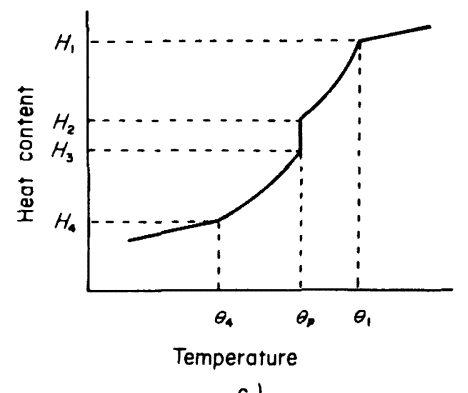

c)

Fig. 4. Relations between temperature and heat content. (a) In the case of $C_{0}<1.0 \%$ and $C_{0}>0.51 \%$, b) $0.10 \%<C_{0}<0.18 \%$ and c) $0.18 \%<C_{0}<0.51 \%$ ).

$$
\begin{aligned}
& H_{1}=s\left(m_{1} C_{0}+\theta_{01}\right)+H_{0}+L \ldots \ldots \ldots \ldots \ldots \ldots \ldots \ldots \ldots \ldots \ldots \ldots \ldots \\
& H_{2}=s \theta_{p}+H_{0}+L \frac{k_{01}}{1-k_{01}} \frac{\theta_{p}-\left[\left(m_{1} / k_{01}\right) C_{0}+\theta_{01}\right]}{\theta_{01}-\theta_{p}}
\end{aligned}
$$

$H_{3}=s \theta_{p}+H_{0}$

i ) $H_{1}<H$ 全部夜相であり, (21) 式にて表わされる.

ii ) $H_{2}<H<H_{1}$ 固液共存範囲であり，(12)式で表わ される.ただし，(12)式中の $b, c$ の各値は， $\left(12^{\prime}\right)$ 式 で $m=m_{1}, k_{0}=k_{01}, \theta_{0}=\theta_{01}$ とした時の值である.

iii) $\mathrm{H}_{3}<\mathrm{H}<\mathrm{H}_{2}$ 固液共存範囲で温度が包晶点にある 場合であり，Hに関係なく，

$$
\theta=\theta_{p}
$$

である.なお，この場合も固相率は(18)式により含熱量 
から計算できる。しかし，温度から固相率を求めること はできず，温度(包晶点)打よび含熱量からは，次の (27) 式によって求めることができる。

$$
f_{s}=\frac{H_{2}-H}{L}+\frac{m_{1} C_{0}+\theta_{01}-\theta_{p}}{\left(1-k_{01}\right)\left(\theta_{01}-\theta_{p}\right)}
$$

iv) $H<H_{3}$ 全部固相であり，(22)式で表わされる.

3) $0.18 \%<C_{0}<0.51 \%$

凝固過程に包晶点を含み, $\bar{o}+L$ 領域の液相線で㠜固 し始め，包晶点を経過し， $\gamma+L$ 領域の固相線で㠜固が 終了する，温度と含熱量の関係は Fig. $4 \mathrm{c}$ ) に示すよ うになる。 $H_{2}$ は (24) 式と同じであり， $H_{3}$ は(11)式で $m=m_{2}, k_{0}=k_{02}, \theta_{0}=\theta_{02}$, かつ $\theta=\theta_{p}$ とおいて求まる.

$\mathrm{H}_{1}, \mathrm{H}_{2}, \mathrm{H}_{3}, \mathrm{H}_{4}$ は次のようである.

$$
\begin{aligned}
& H_{1}=s\left(m_{1} C_{0}+\theta_{01}\right)+H_{0}+L \\
& H_{2}=s \theta_{p}+H_{0}+L \frac{k_{01}}{1-k_{01}} \frac{\theta_{p}-\left[\left(m_{1} / k_{01}\right) C_{0}+\theta_{01}\right]}{\theta_{01}-\theta_{p}} \\
& H_{3}=s \theta_{p}+H_{0}+L \frac{k_{02}}{1-k_{02}} \frac{\theta_{p}-\left[\left(m_{2} / k_{02}\right) C_{0}+\theta_{02}\right]}{\theta_{02}-\theta_{p}}
\end{aligned}
$$

$$
H_{4}=s\left[\left(m_{2} / k_{02}\right) C_{0}+\theta_{02}\right] H_{0}
$$

i) $H_{1}<H$ 全部夜相であり，(21)式で表わされる.

ii ) $H_{2}<H<H_{1}$ 固液共存範囲であり, (12)式で表わ

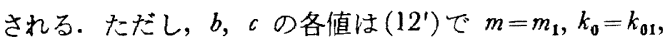
$\theta_{0}=\theta_{01}$ とした時の值である.

iii) $\mathrm{H}_{3}<\mathrm{H}<\mathrm{H}_{2}$ 固液共存範囲で温度が包晶点にある 場合であり，(26)式によって表わされる.

iv) $H_{4}<H<H_{3}$ 固液共存範囲であり，(12)式で表わ される.ただし， $b, c$ の各值は $\left(12^{\prime}\right)$ 式で $m=m_{2}$, $k_{0}=k_{02}, \theta_{0}=\theta_{02}$ とした時の值である.

v ） $H<H_{4}$ 全部固相であり，（22)式によつて表わさ れる.

4) $0.51 \%<C_{0}$

この場合，1）と同様であり, 各式において $m_{1}=m_{2}$, $k_{01}=k_{02}, \theta_{01}=\theta_{02}$ とおけばよい.

\section{6. 計算結果と考察}

\section{1 計算に便用した数値}

状態図に関する数值は Fig. 3 に示した状態図より決 定した． 4，5，で取り扱つたように，計算上，液相線と 固相線は直線であり，かつ， $C=0$ で交わつているとい う前提がある.この前提にしたがつて液相線と固相線を 决定すると， $\delta+L$ 領域では Fig. 3 の状態図と一致す る.

$r+L$ 領域では，液相線と周相線とが $C=0$ で交わり，
Table 1. Data for calculation.

$$
\begin{aligned}
& s=0.1 \mathrm{kcal} / \mathrm{kg} \cdot{ }^{\circ} \mathrm{C} \\
& \rho=7.0 \times 10^{-3} \mathrm{~kg} / \mathrm{m}^{3} \\
& \kappa=31 \mathrm{kcal} / \mathrm{m} \cdot \mathrm{hr} \cdot{ }^{\circ} \mathrm{C} \\
& L=64 \mathrm{kcal} / \mathrm{kg} \\
& H_{0}=-14 \mathrm{kcal} / \mathrm{kg} \\
& m_{1}=-82.3^{\circ} \mathrm{C} / \% \\
& k_{01}=0.196 \\
& \theta_{01}=1536^{\circ} \mathrm{C} \\
& m_{2}=-66.7^{\circ} \mathrm{C} / \% \\
& k_{02}=0.353 \\
& \theta_{02}=1528^{\circ} \mathrm{C} \\
& \theta_{0}=1494^{\circ} \mathrm{C} \\
& d(\text { diameter of specimen })=5.3 \times 10^{-2} \mathrm{~m} \\
& J r=0.164 \times 10^{-2} \mathrm{~m} \\
& \Delta t=0.1 \mathrm{sec}
\end{aligned}
$$

かつ，それぞれJ点とB点を通るように決定した。ただ し, この場合, 状態図の液相線, 固相線とは多少差があ り，C=1.0\% で状態図にくらべて, 液相線は $2^{\circ} \mathrm{C}$ ほ上゙ 高く，固相線は $7^{\circ} \mathrm{C}$ ほど低くなる。

このようにして决定した $\delta+L$ 領域における液相線と 固相線を Fig. 3 において点線にて示した. $m_{1}, k_{01}$ など の数值は, 熱伝導関係の数値, 差分方程式関係の数值と ともに Table 1 に示した、なお，鋳片における半径方向 の分割は 16 等分とした.

\section{2 考 察}

5 の 1)，2)，3)，4）の各場合の代表例として $C_{0}=$ $0.05 \%, 0.15 \%, 0.35 \%, 0.55 \%$ について計算を行な つた. 冷却条件は鋳片表面温度が $15^{\circ} \mathrm{C} / \min$ で降下す るという条件である.

計算結果を Fig. 5 a)， b)，c), d) に示す. 鋳片中 心点では，温度が液相線に達してから，しばらく液相線 より僅か低めの温度にとごまり，温度平衡部を示す。そ の後温度は降下し, 固相線を過ぎるが, 包晶点で㠜固が 終了する Fig. 5 b ) 以外は特に固相線付近にて, 冷却曲 線に特徵的な形は見られない.

液相線より僅か下の温度で，比較的ながく温度平衡部 が現われるのは次の理由によるものと考えられる、いま 凝固過程にある微小鋳片を想定し，この鋳片から一定の 放熱が続くが，この鋳片内では温度勾配がない場合，す なわち，温度降下が非常にゆるやかな場合について考え ると，凝固に伴う含熱量は経過時間に比例して減少す る. この場合の㠜固温度曲線は, Fig. 2 の含熱量の軸 を逆方向に目盛つた時間軸に置きかえたものと同形とな り，液相線付近で温度平衡部が現われる傾向にあること がわかる、また，相変化がなく表面から放熱する固体の 


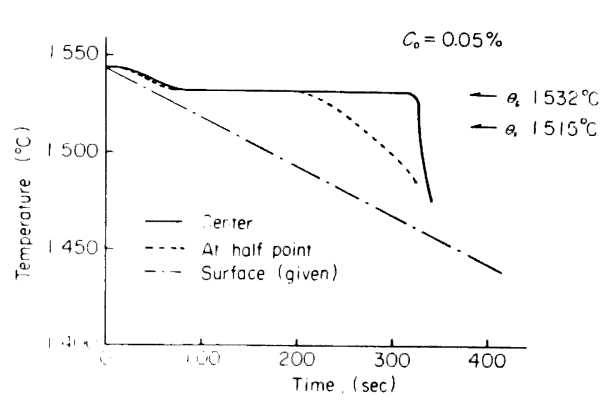

a)

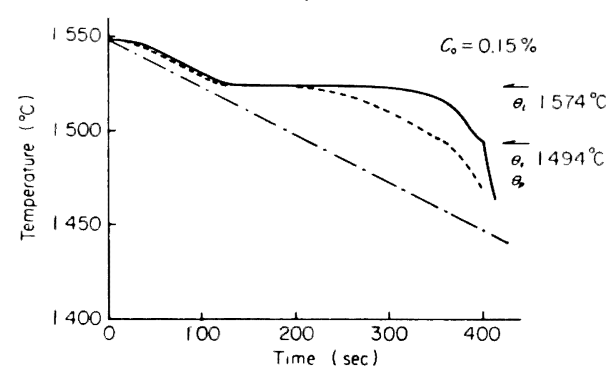

b)

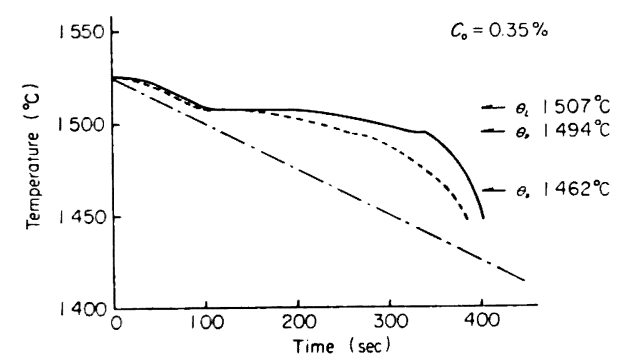

c)

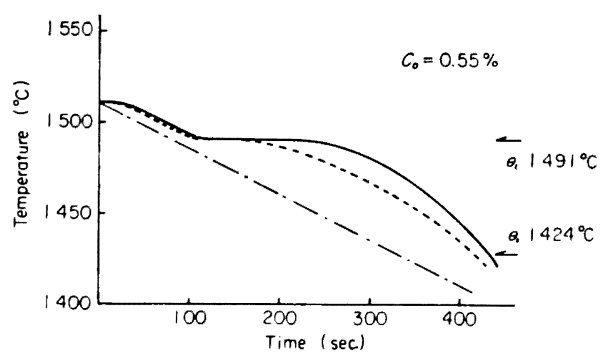

d)

Fig. 5. Calculated time-temperature curves.

(a) $C_{0}=0.05 \%$, b) $C_{0}=0.15 \%$, c) $C_{0}=$ $0.35 \%$ and d) $C_{0}=0.55 \%$ ).

冷却の場合には，中心部は最初はゆつくり温度が降下寸 る.この 2 つの理由から液相線付近にて温度平衡部が現 われるものと考えられる.

Fig. 5 によれば温度平衡部の継続時間は $C_{0}$ の值が小 さい活どながい，实験鋳片により冷却曲線を測定した結

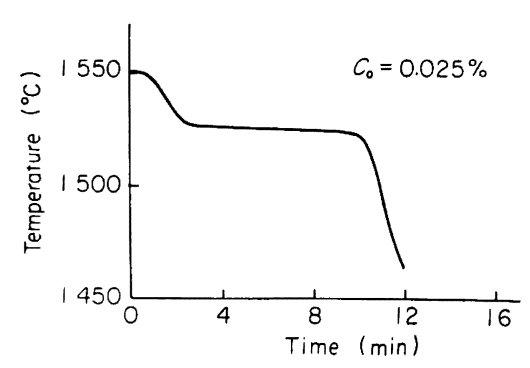

a)

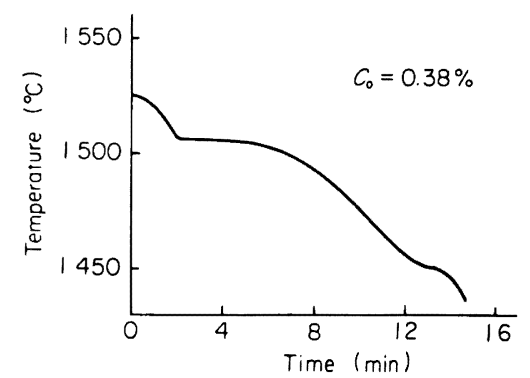

b)

Fig. 6. Measured time-temperature curve.

a) $C_{0}=0.025 \%$ and b) $C_{0}=0.38 \%$ Specimen : $8 \mathrm{~cm} \times 5.3 \mathrm{~cm} \phi$.

果をFig. 6 a)，b）に示す. 実験においては境界条件 を正しく決定することが困難で，計算值と定量的な比較 はできないが， $C_{0}$ に関して同样な傾向を示している.

また，ある適当な時間における鋳片内の固相率分布を Fig. 7 a)，b)，c）に示す. Fig. 7 によれば， $C_{0}$ が小 さい場合は固液共存層の幅は狭く, $C_{0}$ が大きくなるにし たがつて固液共存層の幅は広くなる．固液共存層の幅が 狭い場合, 固相率 1 の場所から固相が堆状に伸びており 堆の断面稆が活相率を表わすと模型的に考えることがで きる.しかし, 固液共存層の幅が広い場合には, 現実に は堆状の间相が啁液共存層の幅だけ細長く伸びていると は考えられず, 固相が伸びているのはある長さに限られ， それ以外の固相剚の低い部分は，これとは別に固相が発 生していると考えることができる．鋳片側面から伸びた 固相が柱状晶を形成し，中心部に発生した固相が等軸晶 を形成すると考えると， $C_{0}$ が大きいほど等軸晶が 表わ れやすい状態となつており， $C_{0}$ の大小が等軸晶生成の 1 要因であるとの推諭ができる. 事実,たとえば,クロム系 ステンレス鋼についてみれば，低炭素ステンレス鋼 403 の鋳造断面はほとんど柱状晶であり, 高炭素ステンレス 鋼 440Cの鋳造断面には等軸晶が多くみられる.

\section{7. 結言}

$\mathrm{Fe}-\mathrm{C}$ 系平衡状態罒による固相析出過程を取入れた鉄 


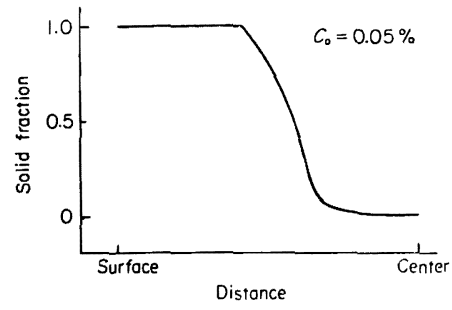

a)

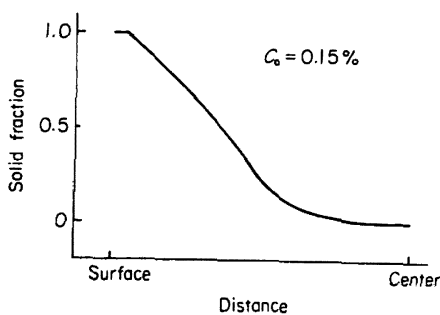

b)

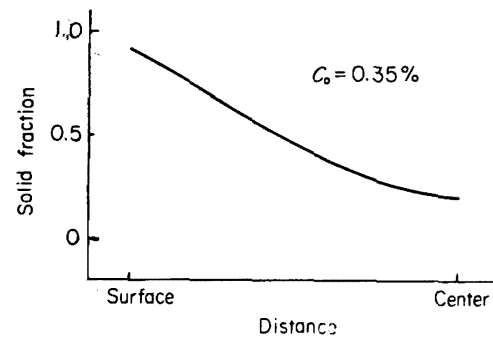

c)

Fig. 7. Calculated distributions of solid fraction.
a) $C_{0}=0.05 \%$,
b) $C_{0}=0.15 \%$ and c) $C_{0}=0.35 \%$ )

銅の凝固モデルを作成し，種々の $C_{0}$ による凝葍泠却曲 線を計算した。

1) 本モデルは $\mathrm{Fe}-\mathrm{C}$ 系平衡状態図に基ゔき，液相お よび固相内の炭素濃度が均一であることを前提とし，凝 固潜熱の放出は固相析出量に比例するとして作成した.

2）計算による冷却曲線については，鋳片の中心部の

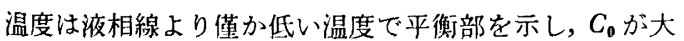
きいほど平衡部の継続時間は短い. 冷却曲線の測定值に おいても同様な傾向を示す.

3） $C_{0}$ が大きいほど固液共存層の幅が広い。この場 合，䥔片中心部に固相晏の低い部分が広く発生し，この 部分が等軸鼠を形成すると考えれば， $C_{0}$ が等軸晶発生 の 1 要因であると推諭される.

\section{記 号}

$C:$ 炭素濃度

$C_{0}:$ 初期液相炭素濃度
$C_{s}$ : 固相, 液相が共存する場合の固相平衡炭素濃度

$C_{L}$ : 固相, 液相が共存する場合の液相平衡炭素濃度

$f_{s}:$ 固相率

$f_{l}:$ 液相率, $f_{l}=1-f_{s}$

$H$ : 含熱量

$H_{1}$ : 凝固開始点に小ける含熱量

$\mathrm{H}_{2}$ : 包晶点に到達した温度における含熱量

$H_{3}$ : 包晶点から温度が降下し始めるときの含熱量

$H_{4}$ : 凝固終了点における含熱量

$k_{0}:$ 平衡分配係数

$m:$ 平衡状態図上に抢ける液相線の傾き

$r:$ 冈筒座標に抢ける半径方向の座標

$s:$ 比熱

$t:$ 時間

$\theta:$ 温度

$\theta_{0}$ : 平衡状態図上で液相線または固相線の $C=0$ にお ける温度

$\theta_{p}:$ 包晶点

$\kappa:$ 熱伝導率

$\rho:$ 密度

$m, k_{0}, \theta_{0}$ に打ける添字の 1 は $\delta+L$ 領域， 2 は $\gamma+$ $L$ 領域を表わす.

付録

液相内で溶質濃度が均一であり，固相内で拡散が全く ない場合の温度と液相率亦たは固相率の関係
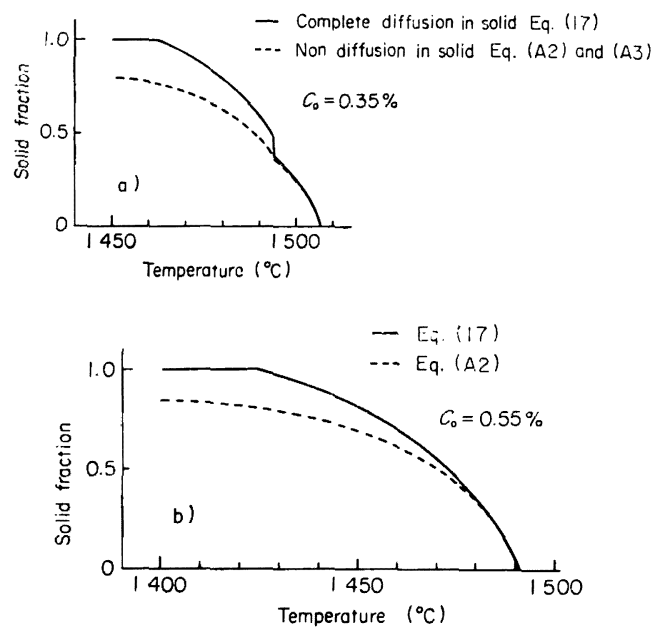

Fig. A 1. Comparisons of relations between temperature and solid fraction in both cases of complete diffusion of carbon in solid and non diffusion of carbon in solid (a) $C_{0}=0.35 \%$ and b) $C_{0}=0.55 \%$ ). 


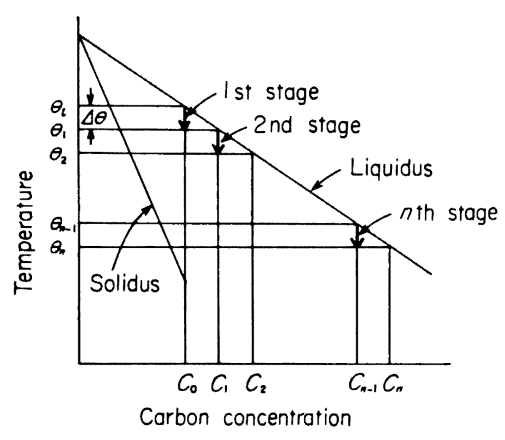

Fig. A2. Procedure for successive calculation of solid fraction in the case of non diffusion of carbon in solid.

1.PFANN の用いた式5)よりの誘導

$C_{s}=k_{0} C_{0}\left(1-f_{s}\right)^{k_{0}-1}$ および固液界面に平衡関係が成 り立つとした $\theta=\left(m / k_{0}\right) C_{s}+\theta_{0}$ の関係から

$$
f_{l}=1-f_{s}=\left(\frac{m C_{0}}{\theta-\theta_{0}}\right)^{1 /\left(1-k_{0}\right)}
$$

が得られる．ただし $C_{s}$ は析出固相濃度である. 式を包晶点を含む場合に拡張すると， $\theta \geqq \theta_{p}$ では（A I) 式と同様,

$$
f_{l}=\left(\frac{m_{1} C_{0}}{\theta-\theta_{01}}\right)^{1\left(/ / 1-k_{01}\right)}
$$

である. また, $\theta<\theta_{p}$ では, $\theta=\theta_{p}$ にて残存する濃度 $C_{p}$ の液相が $\gamma+L$ 領域の液相線と固相線にしたがつて凝固 すると考えればよいから

$$
f_{l}=\left(\frac{m_{1} C_{0}}{\theta_{p}-\theta_{01}}\right)^{1\left(/ 1-k_{01}\right)}\left(\frac{m_{2} C_{p}}{\theta-\theta_{02}}\right)^{1\left(/ 1-k_{02}\right)}
$$

のように表わされる.（A2)，（A3）式により $C_{0}=0.35$ $\%, C_{0}=0.55 \%$ の場合について計算し，固相内で溶質 濃度が均一の場合とともに Fig. Al a)，b)に示した。

2. 逐次計算法

(A2)，（A3）式は1/(1-k0 ）のべき乘の形であるた め数值計算は必ずしも簡単でない。それゆえ，最初から 数値計算を前提とした計算法を考えた.

Fig. A 2 に示すように凝固の過程を不連続な段階に 分けて考える. 第 1 段階で, 温度 $\theta_{l}$, 濃度 $C_{0}$ 単位量の 液相が $\theta_{1}$ に達し, 固相量 $V_{s, 1}$, 残存液相量 $V_{L, 1}$ とな り，さらに第 2 段階で, $V_{L, 1}$ が $\theta_{1}$ から $\theta_{2}$ に達し， $V_{s, 2}$, と $V_{L, 2}$ とになる. 以下，このような不連続な凝固過程 を続けるをのとする.
$V_{s, 1}$ は 濃度 $C_{0}$ の液相が $\theta_{1}$ に達した場合の固相率 $f_{s, 1}$ であるから lever's rule と $\theta_{l}=m C_{0}+\theta_{0}$ より

$$
\begin{aligned}
& V_{s, 1}=f_{s, 1}=\frac{1}{1-k_{0}} \frac{\Delta \theta}{\Delta \theta+m C_{0}} \\
& V_{L, 1}=1-\frac{1}{1-k_{0}} \frac{\Delta \theta}{\Delta \theta+m C_{0}}
\end{aligned}
$$

となる.ただし， $\Delta \theta=\theta_{1}-\theta_{l}$ である.以下，一般に， $\Delta \theta=\theta_{n}-\theta_{n-1}$ である.

次に, 温度 $\theta_{1}$ において濃度 $C_{1}$ の液相が $\theta_{2}$ に達し たときの固相率 $f_{s, 2}$ は

$$
f_{s, 2}=\frac{1}{1-k_{0}} \frac{\Delta \theta}{\Delta \theta+m C_{1}}=\frac{1}{1-k_{0}}-\frac{\Delta \theta}{2 \Delta \theta+m C_{0}}
$$

であるから，第 2 段階で析出する固相量 $V_{s, 2}$ と残存液 相量 $V_{L, 2}$ は

$$
\begin{aligned}
& V_{s, 2}=\frac{1}{1-k_{0}} \frac{\Delta \theta}{2 \Delta \theta+m C_{0}}\left(1-\frac{1}{1-k_{0}} \frac{\Delta \theta}{\Delta \theta+m C_{0}}\right) \\
& V_{L, 2}=\left(1-\frac{1}{1-k_{0}} \frac{\Delta \theta}{2 \Delta \theta+m C_{0}}\right)\left(1-\frac{1}{1-k_{0}} \frac{\Delta \theta}{\Delta \theta+m C_{0}}\right)
\end{aligned}
$$

となる。

このようにして，第 $n$ 段階におけるる析出固相量 $V_{s, n}$ な らびに残存液相量 $V_{L, n}$ は

$$
\begin{aligned}
V_{s, n} & =\frac{1}{1-k_{0}} \frac{J \theta}{n J \theta+m C_{1}} \prod_{\nu=1}^{n-1}\left(1-\frac{1}{1-k_{0}} \frac{\Delta \theta}{\nu \Delta \theta+m C_{0}}\right) \\
\cdots \cdots \cdots \cdots \cdots \cdots \cdots \cdots \cdots(\mathrm{A} 9) & \\
V_{L, n} & =\prod_{\nu=1}^{n}\left(1-\frac{1}{1-k_{0}} \frac{\Delta \theta}{\nu \Delta \theta+m C_{0}}\right) \cdots \cdots \cdots \cdots \cdots(\mathrm{A} 10)
\end{aligned}
$$

と求められる. 温度 $\theta_{n}$ にて存在する固相量すなわち固 相率 $F_{s, n}$ は, 明らかに

$$
F_{s, n}=\sum_{\nu=1}^{n} V_{s, n}
$$

である。

\section{文献}

1) R. H. Tier: Trans. Met. Soc. AIME, 233 (1965), p. 1887

2 ) R. H. Tien and G. E. Geiger: Trans. ASME J. Heat Transfer, (1967)2, p. 230

3 ) R. H. Tien and G. E. Geiger: Trans. ASME J. Heat Transfer, (1968)2, p. 27

4 ) 宮沢, 鞭：鉄と鋼, $60(1972) 7$, p. 262

5 ) W. G. Prann: Trans. AIME J. Metals, 194 (1952) 6, p. 747

6)田中: 鉄と鋼, 53(1967) 14, p. 36 